Article

\title{
Biomimetic Magnetic Nanocarriers Drive Choline Kinase Alpha Inhibitor inside Cancer Cells for Combined Chemo-Hyperthermia Therapy
}

\author{
Ylenia Jabalera ${ }^{1,+}+{ }^{D}$, Alberto Sola-Leyva ${ }^{2,+}$, Ana Peigneux ${ }^{1}$, Federica Vurro ${ }^{3}$, \\ Guillermo R. Iglesias ${ }^{4}$ (D), Jesus Vilchez-Garcia ${ }^{1}$, Inmaculada Pérez-Prieto ${ }^{2}$, \\ Francisco J. Aguilar-Troyano ${ }^{5}$, Luisa C. López-Cara ${ }^{5}$ (D), María P. Carrasco-Jiménez ${ }^{2, *}$ \\ and Concepcion Jimenez-Lopez ${ }^{1, *}$ \\ 1 Department of Microbiology, Faculty of Sciences, University of Granada, 18071 Granada, Spain \\ 2 Department of Biochemistry and Molecular Biology I, Faculty of Sciences, University of Granada, \\ 18071 Granada, Spain \\ 3 Department of Neurosciences, Biomedicine and Movement Sciences, Anatomy and Histology Section, \\ University of Verona, 37134 Verona, Italy \\ 4 Department of Applied Physics, Faculty of Sciences, University of Granada, 18071 Granada, Spain \\ 5 Department of Pharmaceutical and Organic Chemistry, Faculty of Pharmacy, Campus of Cartuja, \\ 18071 Granada, Spain \\ * Correspondence: mpazcj@ugr.es (M.P.C.-J.); cjl@ugr.es (C.J.-L.); \\ Tel.: +34-958-243-248 (M.P.C.-J.); +34-958-249-833 (C.J.-L.) \\ + These authors contributed equally to this work.
}

Received: 2 July 2019; Accepted: 8 August 2019; Published: 12 August 2019

check for updates

\begin{abstract}
Choline kinase $\alpha 1$ (ChoK $\alpha 1)$ has become an excellent antitumor target. Among all the inhibitors synthetized, the new compound Ff35 shows an excellent capacity to inhibit ChoK $\alpha 1$ activity. However, soluble Ff35 is also capable of inhibiting choline uptake, making the inhibitor not selective for ChoK $\alpha 1$. In this study, we designed a new protocol with the aim of disentangling whether the Ff35 biological action is due to the inhibition of the enzyme and/or to the choline uptake. Moreover, we offer an alternative to avoid the inhibition of choline uptake caused by Ff35, since the coupling of Ff35 to novel biomimetic magnetic nanoparticles (BMNPs) allows it to enter the cell through endocytosis without interacting with the choline transporter. This opens the possibility of a clinical use of Ff35. Our results indicate that Ff35-BMNPs nanoassemblies increase the selectivity of Ff35 and have an antiproliferative effect. Also, we demonstrate the effectiveness of the tandem Ff35-BMNPs and hyperthermia.
\end{abstract}

Keywords: biomimetic; magnetic nanoparticle; ChoK $\alpha 1$ inhibitor; Ff35; drug delivery; hyperthermia

\section{Introduction}

Chemoresistance to cancer is a major concern [1,2] that has prompted the development of new effective therapies. Among then, those that affect lipid metabolism, whose alteration occurs in many types of cancer [3,4], have gained great attention. Particularly, the metabolism of choline has been associated with tumor onset and progression. In this context, choline kinase $\alpha 1$ (ChoK $\alpha 1$ ) isoform has been considered as biomarker of tumor progression and carcinogenesis [5-7], and it has emerged as one of the most promising therapeutic target enzymes in cancer. ChoK catalyzes the phosphorylation of choline to generate phosphocholine which, through cytidine 5'-diphosphocholine (CDP-choline) [8], produces phosphatidylcholine. ChoK $\alpha$ also regulates the mitogen-activated protein kinase (MAPK) and phosphoinositide 3-kinase (PI3K/AKT) signaling pathways [9]. Extensive efforts have been made 
to synthesize and improve ChoK $\alpha 1$ inhibitors in order to use them as chemotherapeutic agents [10,11], since it is well known that ChoK $\alpha 1$ inhibitors have antiproliferative effect on several tumor cell lines [12]. Hemicolinium-3 was the first one used in clinics, but it has multiple side effects, mainly due to the inhibition of choline uptake and the impediment of the synthesis of acetylcholine [13]. Afterward, bis-pyridinium and bis-quinolinium derivatives, namely MN58b and RSM-932A, respectively, were also produced with high capacity to inhibit ChoK $\alpha 1$ activity and cell proliferation [14], and, even more recently, several other compounds have been synthesized based on the chemical structure of the former compounds [12]. In particular one of them, here referred as Ff35 (Figure 1), contains bioisoteric rings of the quinoline, where carbon atoms have been replaced by nitrogen and sulphur atoms, and the same spacer as that of the compound MN58b [15]. These changes would lead, on one hand, to an increase of the polarity (and solubility) of the compound and, on the other hand, to an increase of the specificity of the drug. The latter is due to the increasing number of free electron pairs that these modifications induce, which can form hydrogen bonds or dipole-dipole type junctions between the molecule and the enzyme, thus increasing the antiproliferative effect of the drug.

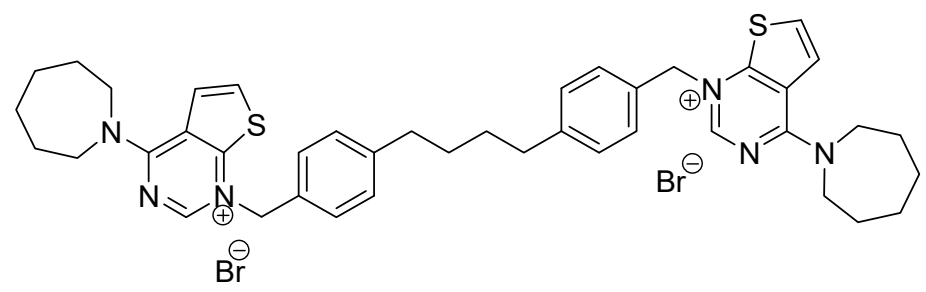

Figure 1. Chemical structure of choline kinase $\alpha 1(\mathrm{ChoK} \alpha 1)$ inhibitor Ff35.

However, it has been described that certain inhibitors of $\mathrm{ChoK} \alpha 1$, besides hemicholinium-3, are also capable of inhibiting choline uptake, thus making it more difficult, if not impossible, for their use in systemic clinical treatments [16]. For this reason, firstly, for any newly synthesized inhibitor of $C h o K \alpha 1$ and before proposing it as antitumoral drug, it is imperative to design protocols to discern whether the resulting inhibition of tumor cell proliferation is due to the inhibition of the enzyme (which would allow the potential use of the compound in clinics) or whether it is caused by the inhibition of the choline uptake (which may prevent its potential use). Moreover, if the latter is the case, it is also crucial to design strategies to avoid the inhibition of choline uptake. A possibility to prevent such inhibition is to use carriers to introduce the specific ChoK $\alpha 1$ inhibitor in the cell without interacting with the choline transporters. In this context, one alternative is to couple the compound with nanoparticles that could enter the cell by endocytosis, as we propose for the first time in the present study.

Among the potential nanocarriers, magnetic nanoparticles are preferred because of their biocompatibility and their magnetic properties, which, on one hand, allow their guidance to the target site and their concentration therein by the application of external magnetic fields and, on the other, they allow the nanoparticle itself to be used as hyperthermia agent [17]. Biomimetic magnetic nanoparticles, BMNPs, mediated by Magnetococcus marinus MC-1 magnetosome membrane protein MamC, have demonstrated themselves to be promising nanocarriers, able to couple with drugs forming stable nanoassemblies at physiological $\mathrm{pH}$, while efficiently releasing the drug in acidic (tumor) environments in response to $\mathrm{pH}$ changes. In fact, these BMNPs present novel features compared to other nanoparticles produced inorganically and/or other biomimetic nanoparticles [18]: (1) They are superparamagnetic (single magnetic domain) at room and body temperature, behaving as nonmagnetic in the absence of an external magnetic field (thus minimizing aggregation), while they present a large magnetic moment per particle under the influence of an external magnetic field, thus optimizing their guidance and concentration at the target site. Such behavior is due to the fact that these BMNPs are larger than most commercial and/or other biomimetic magnetic nanoparticles. (2) the BMNPs are cytocompatible and even more, (3) they are produced by means of an eco-friendly, cost effective, easily scalable method. 
To our understanding, this is the first study that explores the functionalization of BMNPs with a ChoK $\alpha 1$ inhibitor, such as Ff35, with the goal of obtaining a potential nanoassembly suitable for a targeted chemotherapy that avoids possible side effects related to the inhibition of the choline uptake. Moreover, the simultaneous use of hyperthermia is explored to optimize the effect of the targeted chemotherapy in terms of increasing the cytotoxic effect of the nanoassembly. The in vitro antitumor activity and the internalization of these complexes were investigated in the human hepatoblastoma cell line, HepG2.

\section{Materials and Methods}

\subsection{Expression and Purification of MamC. Synthesis and Characterization of the BMNPs by Transmission Electron Microscop}

MamC expression and purification was performed as previously described by Valverde-Tercedor et al. [19]. Escherichia coli TOP10 (Invitrogen, Grand Island, NY, USA) were transformed with the pTrcHis-TOPO plasmid (Invitrogen, Grand Island, NY, USA) carrying the MamC protein coding gene (Mmc1_2265). These cells were grown at $37^{\circ} \mathrm{C}$ and MamC overproduction was induced with isopropyl-1-thio- $\beta$-D-galactopyranoside (IPTG). Afterwards, a HiTrap chelating HP column (Ge Healthcare, Chicago, IL, USA) in an ÄKTA Prime Plus FPLC System (GE Healthcare, Chicago, IL, USA) was used to purify the protein under denaturing conditions (6 $\mathrm{M}$ urea). Lastly, dialysis was performed for a gradual removal of urea, which allowed MamC to refold progressively and the purity was evaluated by SDS-PAGE electrophoresis.

BMNPs were synthesized from the following master solution: $10 \mu \mathrm{g} \mathrm{mL} \mathrm{L}^{-1}$ of the recombinant MamC, $\mathrm{Fe}\left(\mathrm{ClO}_{4}\right)_{2}(2.78 \mathrm{mM}), \mathrm{NaHCO}_{3} / \mathrm{Na}_{2} \mathrm{CO}_{3}(3.5 \mathrm{mM} / 3.5 \mathrm{mM}), \mathrm{FeCl}_{3}(5.56 \mathrm{mM}), \mathrm{pH}$ 9, elaborated from oxygen-free stock concentrated solutions of the individual compounds [20]. The master solution was incubated for 30 days in an anaerobic COY chamber at $25^{\circ} \mathrm{C}$ and $1 \mathrm{~atm}$ total pressure. After this time, BMNPs were concentrated by using a magnet and the supernatant was discarded. Subsequently, the precipitates were washed three times with Milly-Q deoxygenated water, suspended in HEPES (4-(2-hydroxyethyl)-1-piperazineethanesulfonic acid) buffered saline solution (0.01 M HEPES, pH 7.2, $0.15 \mathrm{M} \mathrm{NaCl}$ ), and sterilized at $121^{\circ} \mathrm{C}$ for $21 \mathrm{~min}$ in an autoclave before their use.

The BMNPs used in the present study have been previously characterized in García-Rubia et al. [18], and, therefore, only basic mineral characterization is included in the present manuscript. According to these results, the BMNPs used in the present study are superparamagnetic magnetic nanoparticles at $300 \mathrm{~K}$, composed of $\sim 95 \mathrm{wt} \%$ of magnetite and $\sim 5 \mathrm{wt} \%$ of MamC, with an isoelectric point of 4.4 and specific surface area of $90 \mathrm{~m}^{2} / \mathrm{g}$.

For transmission electron microscopy (TEM) analyses of the BMNPs, a STEM Philips Model CM20 microscope was used. BMNPs were embedded into Embed 812 resin and then, ultrathin sections (50-70 nm) were cut with a Reichert Ultracut S microtome (Leica Microsystems GmbH, Wetzlar, Germany). ImageJ 1.47 software was used to measure particle sizes on multiple micrographs with over 1000 nanoparticles measured for each experiment to ensure reproducibility.

Hysteresis cycles and zero field cooling-field cooling (ZFC-FC) curves were carried out by using a superconducting quantum interference device (SQUID) 5 T magnetometer (Quantum Design MPMS $\mathrm{X}$, San Diego, CA, USA). Blocking temperature $\left(\mathrm{T}_{\mathrm{B}}\right)$ was calculated as the temperature at which the maximum in magnetization occurred in ZFC curve.

\subsection{Formation of Ff35-BMNPs Nanoassemblies}

The kinetics of Ff35 adsorption on the magnetic nanoparticles was studied to determine the time required for this adsorption to reach equilibrium. In these experiments, an aliquot of $5 \mathrm{mg}$ of BMNPs was mixed with $1 \mathrm{~mL}$ of Ff35 $100 \mu \mathrm{M}$ in HEPES buffer (10 mM HEPES, $150 \mathrm{mM} \mathrm{NaCl}, \mathrm{pH} 7.2$ ) for several time intervals up to $48 \mathrm{~h}$. After the incubation time, the Ff35-BMNPs nanoassemblies (here referred as Ff35-BMNPs) were collected with a magnet and washed twice with HEPES buffer. 
Then, the supernatants were measured by UV-Vis spectroscopy at a wavelength of $304 \mathrm{~nm}$ and these measurements were used to calculate the percentage of the absorbed compound. The molar absorptivity of Ff35 in HEPES buffer at $304 \mathrm{~nm}$ was determined as $2677.5 \mathrm{~L} \mathrm{~mol}^{-1}\left(R^{2}=0.9991\right)$ from the slope of a standard calibration straight line. More than three replicas were performed per experiment. The standard deviation of the absorbance measurements was used to calculate the error in the concentration of Ff35 in the supernatant $\left([F f 35]_{s n}\right)$.

The adsorption isotherm to calculate the saturation concentration of Ff35 adsorbed on the BMNPs was determined by mixing an aliquot of $5 \mathrm{mg}$ of BMNPs with $1 \mathrm{~mL}$ of several concentrations of Ff35 (ranging from 0 up to $200 \mu \mathrm{M}$ ) in HEPES buffer. These preparations were incubated at $25^{\circ} \mathrm{C}$ under continuous stirring for $6 \mathrm{~h}$ (time needed to reach equilibrium, according to the kinetics experiments). Three replicas were performed per each measurement. After the incubation time, supernatants were harvested, particles were washed, and UV-Vis spectroscopy measurements of all supernatants were performed as described above. The data were fitted to the model of Langmuir-Freundlich (LF) by using Origin 8. The LF model is based on Equation (1), where $(Q)$ is the amount of adsorbed drug per mass unit of adsorbent, $\left(C_{e}\right)$ is the amount of nonadsorbed compound, $\left(K_{L F}\right)$ is the LF affinity constant, and $(r)$ is the cooperativity coefficient. A value of $r<1$ means a negative cooperativity whereas a value of $r>1$ means a positive cooperativity [18,21].

$$
Q=\frac{Q_{\max }\left(K_{L F} C_{e}\right)^{r}}{1+\left(K_{L F} C_{e}\right)^{r}} .
$$

\subsection{Cell Culture}

The human hepatoblastoma HepG2 cell line, used in this work, was acquired from the European Collection of Animal Cell Cultures (Salisbury, UK). The cells were grown in Minimum Essential Medium (MEM) containing 10\% heat-inactivated fetal bovine serum (FBS) supplemented with $2 \mathrm{mM}$ L-glutamine, $1 \%$ nonessential amino acids, $100 \mathrm{U} \mathrm{mL}^{-1}$ penicillin, and $100 \mu \mathrm{g} \mathrm{mL} \mathrm{m}^{-1}$ streptomycin in a humid atmosphere with $5 \% \mathrm{CO}_{2}$ as $37^{\circ} \mathrm{C}$, and subcultured at a ratio of 1:10 once a week.

\subsection{Inhibition of Choline Kinase $\alpha 1$ by Ff35}

The effect of $\mathrm{Ff} 35$ on ChoK was assayed in purified ChoK $\alpha 1$ as previously described by Schiaffino et al. [12], by determining the rate of incorporation of ${ }^{14} \mathrm{C}$ from [methyl $\left.-{ }^{14} \mathrm{C}\right]$ choline into phosphocholine, both in the absence (control) or presence of different inhibitor concentrations. Briefly, the final reaction mixture contained $100 \mathrm{mM}$ Tris- $\mathrm{HCl}$ ( $\mathrm{pH} 8.5), 10 \mathrm{mM} \mathrm{MgCl}_{2}, 10 \mathrm{mM}$ ATP, and $20 \mathrm{ng}$ of purified $\mathrm{ChoK} \alpha 1$. The reaction was initiated with $1 \mathrm{mM}\left[\right.$ methyl $\left.-{ }^{14} \mathrm{C}\right]$ choline $(4500 \mathrm{dpm} / \mathrm{nmol})$ and incubated at $37^{\circ} \mathrm{C}$ for $10 \mathrm{~min}$. The assay was stopped by immersing the reaction tubes in boiling water for $3 \mathrm{~min}$. Aliquots of the reaction were applied to the origin of silica gel plates in the presence of phosphocholine $(0.1 \mathrm{mg})$ and choline $(0.1 \mathrm{mg})$ as carriers. The chromatography was developed in methanol/ $/ 0.6 \%$ $\mathrm{NaCl} / 28 \% \mathrm{NH}_{4} \mathrm{OH}$ in water $(50: 50: 5, v / v / v)$ as solvent, and phosphocholine was visualized under exposure to iodine vapour. The corresponding spot was scraped and transferred to scintillation vials for measurement of radioactivity by a Beckman 6000-TA (Madrid, Spain) liquid-scintillation counter. The $50 \%$ inhibitory concentrations $\left(\mathrm{IC}_{50}\right.$ value) were determined from the $\%$ activity of the enzyme at different concentrations of synthetic inhibitor by using a sigmoidal dose-response curve (the ED50plus v1.0 software).

\subsection{Cell Proliferation Assay}

HepG2 cells were seeded onto 96-well plates (10000 cells/well) and grown in MEM/10\% FBS for $24 \mathrm{~h}$. After $24 \mathrm{~h}$, the medium was removed and $100 \mu \mathrm{L}$ of fresh medium containing Ff35 $(1,5$, and $10 \mu \mathrm{M})$, BMNPs $\left(300 \mu \mathrm{g} \mathrm{mL}^{-1}\right)$, or Ff35-BMNPs (Ff35 $1 \mu \mathrm{M}$ and BMNPs $300 \mu \mathrm{g} \mathrm{mL}^{-1}$ ) were added for different times. Cell viability was assayed by the MTT (3-(4,5-dimethylthiazol-2-yl)-2,5-diphenyltetrazolium bromide). Formazan crystals were dissolved in $100 \mu \mathrm{L}$ of DMSO, and the absorbance was read at a 
wavelength of $570 \mathrm{~nm}$ using a microplate reader (HTX Microplate Reader BioTek Instruments, Winooski, VT, USA). The GI $_{50}$ (half-maximal growth inhibitory concentration) value was determined from the $\%$ cell viability at different concentrations of synthetic inhibitor by using a sigmoidal dose-response curve (the ED50plus v1.0 software), referencing this value to an untreated cells control taken as a $100 \%$ of the viability.

\subsection{Inhibition of Choline Uptake by Ff35 and Ff35-BMNPs}

Choline uptake was assayed as previously reported [22]. HepG2 cells were incubated for $10 \mathrm{~min}$ at $37^{\circ} \mathrm{C}$ in a MEM/10\% FBS medium containing soluble Ff35 (0.5 and $\left.1 \mu \mathrm{M}\right)$, BMNPs $\left(300 \mu \mathrm{g} \mathrm{mL}{ }^{-1}\right)$, or Ff35-BMNPs (concentration of Ff35 was $0.5 \mu \mathrm{M}$ and BMNPs was $150 \mu \mathrm{g} \mathrm{mL} \mathrm{m}^{-1}$ or that of Ff35 was $1 \mu \mathrm{M}$ and BMNPs was $300 \mu \mathrm{g} \mathrm{mL}^{-1}$ ). After $10 \mathrm{~min}, 24 \mathrm{~h}$, and $48 \mathrm{~h}$ of treatment, the cells were immediately exposed to a pulse of [methyl- $\left.{ }^{14} \mathrm{C}\right]$ choline $\left(16 \mu \mathrm{M}, 31 \mathrm{Ci} / \mathrm{mol}\right.$, in well) for $5 \mathrm{~min}$ at $37^{\circ} \mathrm{C}$. The incorporation of choline was stopped by medium aspiration followed by two washes in ice-cold PBS containing $580 \mu \mathrm{M}$ choline. Then, the cells were solubilized in $\mathrm{NaOH} 0.1 \mathrm{~N}$ and an aliquot was used to determine the total amount of radiolabeled choline taken up by the cells, measured by liquid scintillation using a Beckman 6000-TA counter (Madrid, Spain).

\subsection{Internalization of BMNPs or Ff535-BMNPs in the Cells}

HepG2 cells were grown in six-well dishes for $24 \mathrm{~h}$. Then, BMNPs $\left(300 \mu \mathrm{g} \mathrm{mL} \mathrm{m}^{-1}\right.$ ) or Ff35-BMNPs (concentration of Ff35 was $1 \mu \mathrm{M}$ and BMNPs was $300 \mu \mathrm{g} \mathrm{mL}{ }^{-1}$ ) or only MEM/10\% FBS medium, as a control, were added for $24 \mathrm{~h}$. Cells were collected using trypsin and centrifuged at $1500 \mathrm{rpm}$ for $5 \mathrm{~min}$ in MEM/10\% FBS. Cell pellets were fixed in $2.5 \%$ glutaraldehyde and $2 \%$ paraformaldehyde in $0.05 \mathrm{M}$ cacodylate buffer for $4 \mathrm{~h}$ at $4{ }^{\circ} \mathrm{C}$. The samples were washed three times with cacodylate buffer and postfixed in an aqueous solution of $1 \% \mathrm{OsO}_{4}$ containing $1 \%$ potassium ferrocyanide for $1 \mathrm{~h}$ at $4{ }^{\circ} \mathrm{C}$ in darkness. The following washes were done $\left(25^{\circ} \mathrm{C}\right): 0.15 \%$ tannic acid in cacodylate buffer, cacodylate buffer, and $\mathrm{H}_{2} \mathrm{O}$. The samples were left in $2 \%$ uranyl acetate for $2 \mathrm{~h}$ and washed several times with $\mathrm{H}_{2} \mathrm{O}$. Then, dehydration in ethanol solutions rising from $50 \%$ to $100 \%$ was done at $4{ }^{\circ} \mathrm{C}$. The samples were embedded in resin (EMbed 812/100\% ethanol (1/1)) for 60 min at room temperature, the same resin at a 2/1 ratio for $60 \mathrm{~min}$, and then resin without ethanol overnight. For polymerization, the samples were incubated in pure resin for $48 \mathrm{~h}$ at $60^{\circ} \mathrm{C}$. Ultrafine sections $(50-70 \mathrm{~nm})$ were cut using a Leica Ultramicrotome $\mathrm{R}$ and contrasted using 1\% aqueous uranyl acetate for 5 min and lead citrate in a $\mathrm{CO}_{2}$-depleted atmosphere for $4 \mathrm{~min}$ [23]. A Zeiss Libra Plus 120 electron microscope was used to visualize the sections.

\subsection{Hyperthermia Analysis}

Magnetic hyperthermia experiments were carried out using a laboratory-built AC current generator, based on a Royer-type oscillator. The AC source was connected to a double five-turn coil built with a copper tube $4 \mathrm{~mm}$ in diameter. This allowed control of the temperature of the coil by flowing thermostated water. The coil was $20 \mathrm{~mm}$ in diameter and $45 \mathrm{~mm}$ long. The magnetic field frequency was $197 \pm 3 \mathrm{kHz}$, and its strength was $H=21 \mathrm{kA} / \mathrm{m}(B=26.4 \mathrm{mT}$ in air $)$ at the center of the coil, where the samples were placed, measured with a NanoScience Laboratories Ltd., Probe (Newcastle, UK), with $10 \mu \mathrm{T}$ resolution. All samples were previously prethermostated at $37^{\circ} \mathrm{C}$. Prior to any determination, the adiabatic condition of the system was verified by subjecting a sample of Milli-Q water as control, in order to ensure that any temperature changes in the samples under study were due to the action of the magnetic field, and not a consequence of environmental temperature gradient. A preliminary experiment was performed with a suspension of bare BMNPs $\left(300 \mu \mathrm{g} \mathrm{mL}{ }^{-1}\right)$ to set the conditions (frequency and strength of the field and time of application) needed to guarantee that a temperature of $43{ }^{\circ} \mathrm{C}$ was reached. The sample temperature was determined with an optical fiber thermometer (Optocon AG, Dresden, Germany). For actual hyperthermia experiments, HepG2 cells were incubated for $24 \mathrm{~h}$ at $37^{\circ} \mathrm{C}$ with either $300 \mu \mathrm{g} \mathrm{mL}{ }^{-1}$ BMNPs or Ff35-functionalized BMNPs and exposed to the 
$\mathrm{AC}$ magnetic field for time lapses ranging between 1 and $3 \mathrm{~h}$. Immediately after the hyperthermia treatment, the cells were processed for the MTT test.

\subsection{Statistics}

The results are shown as averages \pm SEM. A one-way ANOVA was done with post hoc comparisons by Scheffé's test (SPSS 13.0). $p<0.05$ is considered statistically significant.

\section{Results and Discussion}

BMNPs exhibited well-developed faces and a size ranging from 20 to $50 \mathrm{~nm}$, with an average crystal size of $35 \pm 8 \mathrm{~nm}$, according to TEM analyses (Figure 2A,B). The hysteresis loop of BMNPs showed a typical ferromagnetic behavior at $5 \mathrm{~K}$, while at $300 \mathrm{~K}$, these nanoparticles showed zero coercivity, which indicates their superparamagnetic character, being that the magnetization saturation (Ms) was at $300 \mathrm{~K} 55 \mathrm{emu} / \mathrm{g}$ (Figure 2C,D). The ZFC-FC curves at 500 Oe show a slow increase in magnetization (Figure 2E). In fact, the $\mathrm{T}_{\mathrm{B}}$ was $150 \mathrm{~K}$ for BMNPs. According to Prozorov et al. [17], this higher $\mathrm{T}_{\mathrm{B}}$ and slow magnetization increase is related to particles that expose a large magnetic moment per particle and high crystallinity.
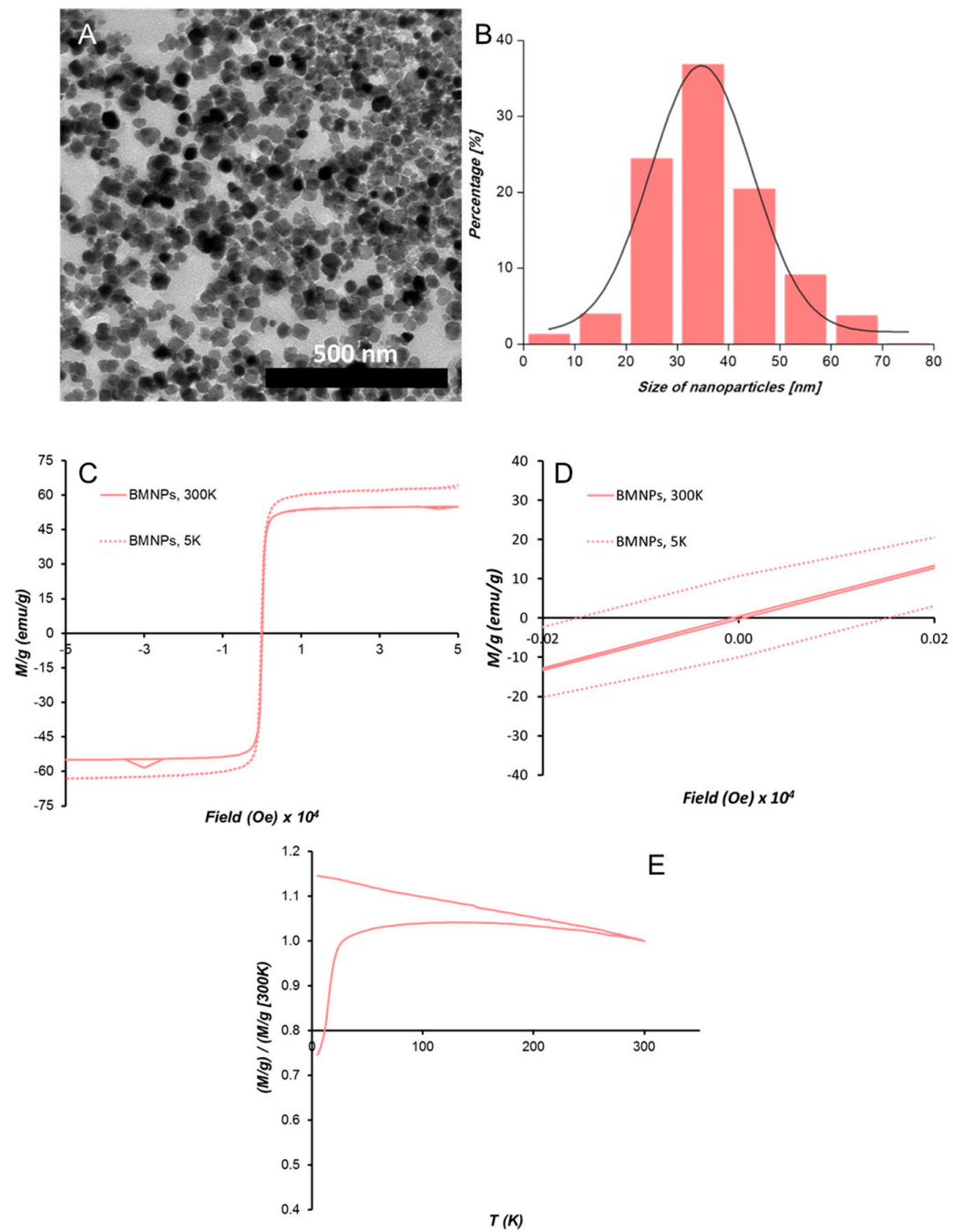

Figure 2. Biomimetic magnetic nanoparticles (BMNPs) characterization. (A) TEM image of BMNPs and (B) crystal size distribution. (C) Hysteresis cycle of BMNPs at $300 \mathrm{~K}$ and $5 \mathrm{~K}$. (D) Detail of the hysteresis cycle in the absence of external magnetic field at $300 \mathrm{~K}$ and $5 \mathrm{~K}$. (E) Zero field cooling-field cooling (ZFC-FC) curves of BMNPs. 
The kinetics of Ff35 adsorption on BMNPs over time shows that the system reached equilibrium at $\sim 6 \mathrm{~h}$ (Figure $3 \mathrm{~A}$ ). The amount of adsorbed drug per amount of nanoparticles $(Q)$ increased with the equilibrium concentration of $F f 35$ in the supernatant $\left(C_{e}\right)$ at a higher rate at the lowest $C_{e}$ values. Such a rate decreased as $C_{\mathrm{e}}$ increased (Figure $3 \mathrm{~B}$ ). The adsorption isotherm adjusts to the Langmuir-Freundlich (LF) models $\left(R^{2}=0.93402\right)$, showing a drug loading capacity $\left(Q_{\max }\right)$ of $0.0026 \pm 0.0003 \mathrm{mg}$ Ff35 mg magnetite $^{-1}$. This model introduces the effects of energetic heterogeneity of the surface and the cooperativity between Ff35 molecules, meaning that once a Ff35 molecule is coupled to BMNPs, it lowers the energy required for the coupling of the next ones. The values of the LF affinity constant $\left(K_{L F}\right)$ and cooperativity coefficient $(r)$ parameters, calculated by means of this model were of $40 \pm 10 \mathrm{mg}$ of Ff35 per mg of magnetite and $1.5 \pm 0.6$, respectively.
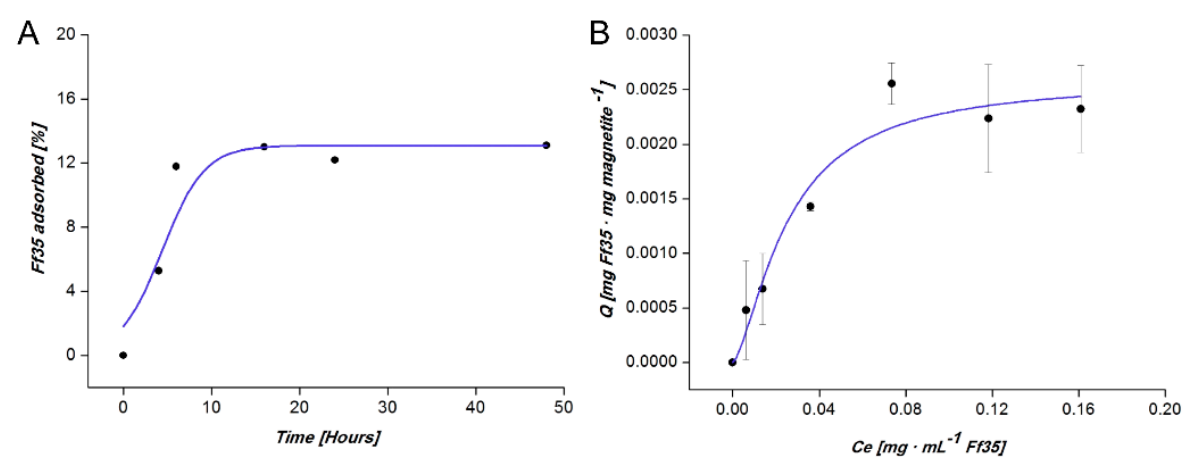

Figure 3. Adsorption kinetics (A) and adsorption isotherm (B) of Ff35 on BMNPs. The line represents the nonlineal weighted least-squares (NWLS) fitting of the experimental data according to LF model. In the case of adsorption kinetics, the vertical error bars are smaller than the symbol.

Our results show that BMNPs are able to carry $0.0026 \mathrm{mg}$ of Ff35 per mg of magnetite $\left(Q_{\max }\right)$. Due to the fact that this is the first study on Ff35 adsorption on magnetite nanoparticles (or on any other nanoparticles), comparisons of the $Q_{\max }$ of the present study are done in reference to other studies involving either the BMNPs used here or other nanocarriers. The $Q_{\max }$ value obtained in the present manuscript was lower than those values obtained for the coupling of other drugs like doxorubicin (DOXO) to BMNPs. For example, the adsorption of DOXO on the same BMNPs was $0.69 \pm 0.03 \mathrm{mg}$ $\mathrm{DOXO} / \mathrm{mg}$ BMNPs [18] or $0.41 \pm 0.03 \mathrm{mg} \mathrm{DOXO} / \mathrm{mg}$ apatite for DOXO adsorption on citrate-coated apatite [24]. Even though $Q_{\max }$ for Ff35 is about two orders of magnitude lower than that for other compounds, this amount that is coupled to the BMNPs is enough to have a cytotoxic effect as it will be shown below.

The BMNPs' loading capacity could be explained, on the one hand, by the electrostatic interaction occurring at $\mathrm{pH} 7.2$ ( $\mathrm{pH}$ value at which the coupling occurs) between Ff35, which exposes two basic groups, positively charged and the negatively charged magnetite surface (isoelectric point (iep) $=4.4)$ [18], which allows Ff35 to be bound to the BMNPs, as previously demonstrated for other nanoassemblies involving BMNPs and positively charged molecules [18]. However, when the environmental $\mathrm{pH}$ decreases approaching the iep of the BMNPs (as it naturally does in a tumor environment, for instance, in the endosome-lysosome compartment [25]), the electrostatic interactions between Ff35 and BMNPs weaken, prompting Ff35 release. This characteristic presents a relevant point for the potential clinical application of Ff35-BMNPs nanoassemblies, since no Ff35 release is expected in the bloodstream until the nanoparticles reach the target tumoral (acidic) environment. On the other hand, the results show that not only electrostatic interactions between the drug and the BMNPs would be responsible for the Ff35-BMNPs nanoassemblies formation, since the $r$ coefficient obtained in LF model $(r>1)$ demonstrates a strong positive cooperativity between the molecules of Ff35 during the adsorption process. This type of interaction has been previously described in DOXO adsorption on citrate-coated apatite nanocrystals [24] and on BMNPs [18]. 
Soluble Ff35 show a negative effect on HepG2 cell growth in a time and concentration-dependent manner (Figure $4 \mathrm{~A}$ ). The $\mathrm{IC}_{50}$ values derived from the growth inhibition curves were of $6.23 \pm 0.39$, $1.37 \pm 0.004$, and $0.45 \pm 0.10 \mu \mathrm{M}$ for 24,48 , and $72 \mathrm{~h}$, respectively. Lactate dehydrogenase (LDH) activity in the culture medium was not detected after any of the treatments up to $10 \mu \mathrm{M}$ of Ff35 (data not shown), so the decrease in cell proliferation observed after the treatment with soluble Ff35 could not be attributed to any acute cytotoxicity produced by plasma-membrane leakage. Ff35-BMNPs also significantly decreased cell growth after 24 or 48 h of treatment. HepG2 cell proliferation was not affected by the presence of BMNPs, which demonstrates the cytocompatibility of the BMNPs.

A

B
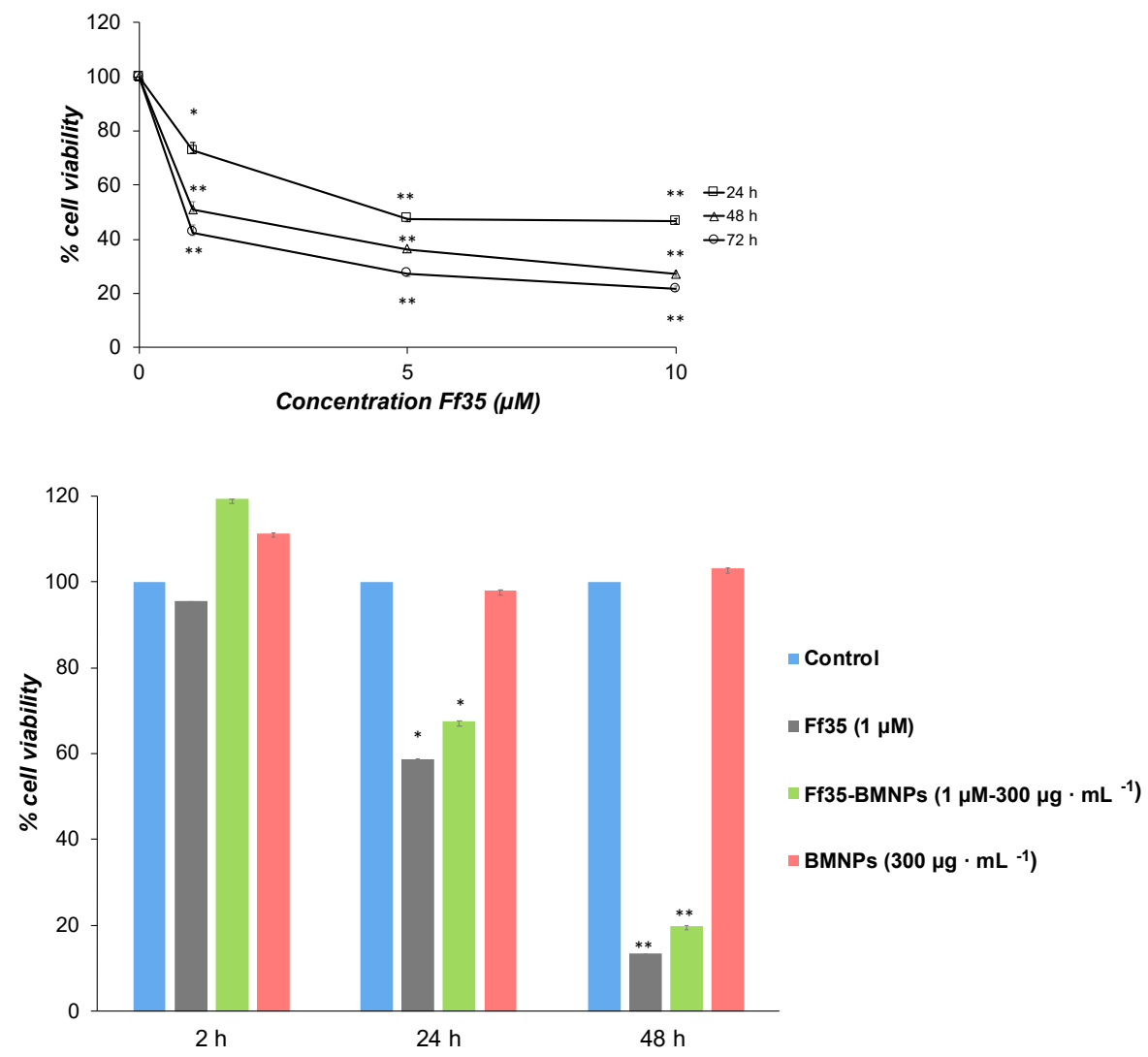

Figure 4. Effects of Ff35, BMNPs, and Ff35-BMNPs on HepG2 cell proliferation. HepG2 cells growing in the log phase were incubated with Minimum Essential Medium containing 10\% heat-inactivated fetal bovine serum (MEM/10\% FBS) in the presence or absence of Ff35 up to $10 \mu \mathrm{M}(\mathbf{A})$ or Ff35 $1 \mu \mathrm{M}$, BMNPs $300 \mu \mathrm{g} \mathrm{mL}^{-1}$ or Ff35-BMNPs (concentration of Ff35 was $1 \mu \mathrm{M}$ and that of BMNPs was $300 \mu \mathrm{g} \mathrm{mL}^{-1}$ ) (B). Cell viability was determined by MTT assay and normalized to that of the respective control cells. These experiments were performed twice in triplicate. ${ }^{*} p<0.05,{ }^{* *} p<0.001$ compared to their respective controls.

Soluble Ff35 inhibits the activity of ChoK $\alpha 1$ (Figure $5 \mathrm{~A}$ ), with an $\mathrm{IC}_{50}$ value of $0.46 \pm 0.079 \mu \mathrm{M}$. In addition, choline uptake was also inhibited in the presence of soluble Ff35 in $55 \%$ and $75 \%$ at $0.5 \mu \mathrm{M}$ and $1 \mu \mathrm{M}$, respectively, after only $10 \mathrm{~min}$ of exposure. The effect was even more noticeable after 24 or $48 \mathrm{~h}$ of treatment, reaching inhibition levels of up to $68 \%$ and $88 \%$ at Ff $350.5 \mu \mathrm{M}$ and $1 \mu \mathrm{M}$, respectively, after $48 \mathrm{~h}$ of treatment (Figure 5B). These results clearly indicate that soluble Ff35 inhibits strongly both choline activity and absorption, and that the action of this compound in both processes is associated with a decrease in cell proliferation.

Interestingly, the treatment with Ff35-BMNPs for 10 min did not produce significant changes in the incorporation of choline into the cells compared with cells treated with BMNPs (Figure 5B) or in control cells (Figure 5B). After $24-48$ h of treatment, only a significant inhibition of choline uptake was 
observed at a concentration of Ff35 $1 \mu \mathrm{M}$ and BMNPs $300 \mu \mathrm{g} \mathrm{mL}{ }^{-1}$. Nevertheless, this inhibition was much lower than that observed with soluble Ff35 at the same concentration. The results indicate that the functionalization of BMNPs with Ff35 strongly reduces the inhibitory effect of Ff35 on choline uptake. To avoid completely the action of Ff35 on choline uptake, it would be necessary to control the concentration of Ff35 as well as the time of treatment. It is likely that after a long treatment there may be some release of the compound from the BMNPs that were not endocitated. This released Ff35 may be responsible for the slight inhibition observed during treatment with Ff35-BMNPs (Ff35-BMNPs $1 \mu \mathrm{M}$ and BMNPs $300 \mu \mathrm{g} \mathrm{mL}{ }^{-1}$ ). However, the amount of compound released from Ff35-BMNPs (Ff35-BMNPs $0.5 \mu \mathrm{M}$ and BMNPs $150 \mu \mathrm{g} \mathrm{mL}{ }^{-1}$ ) was not sufficient to inhibit choline uptake.
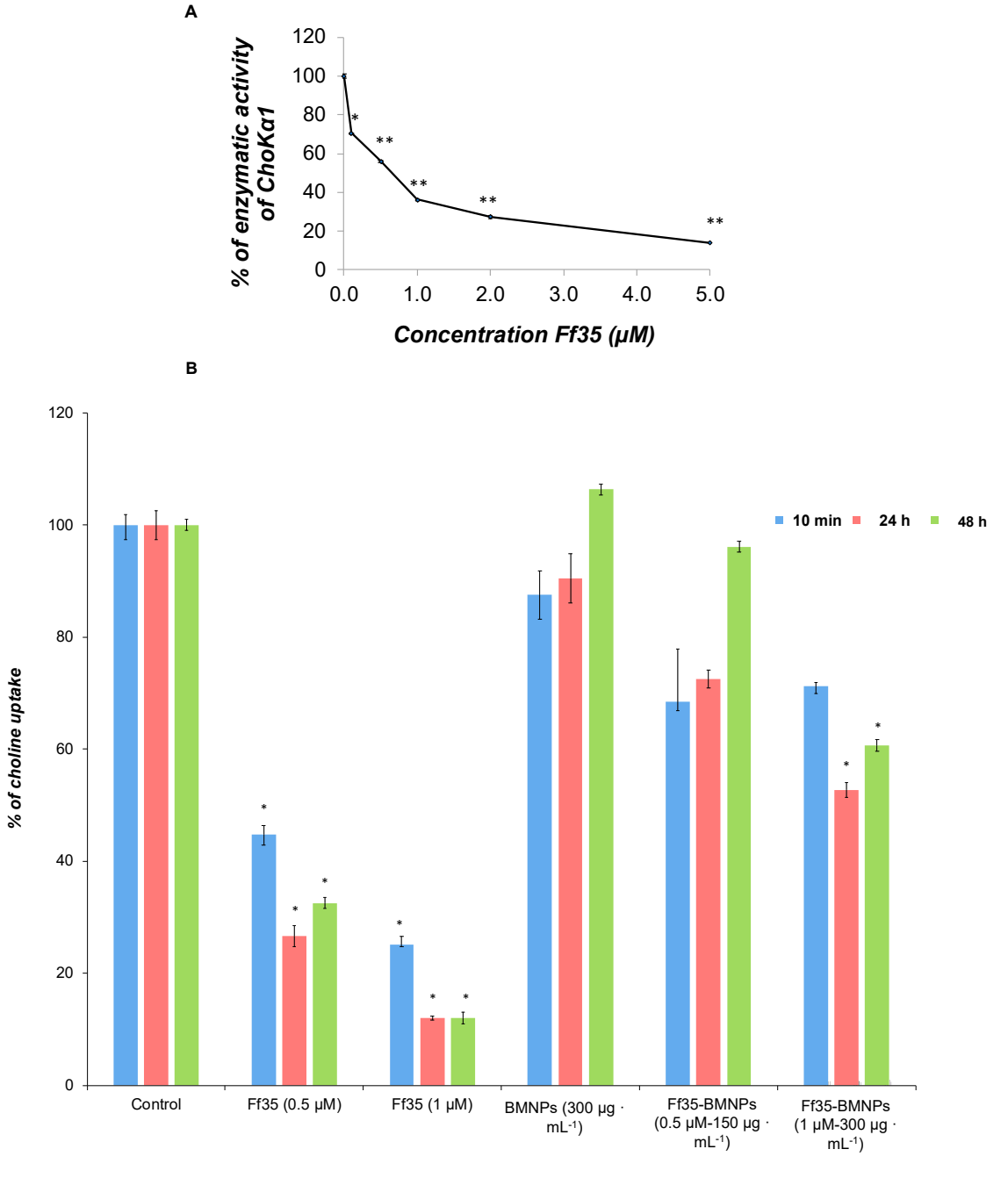

Figure 5. (A) Effects of Ff35 on ChoK $\alpha 1$ activity assayed in purified ChoK $\alpha 1$ exposed to different Ff35 concentrations. The results are expressed as percentage of enzymatic inhibition. (B) Choline uptake assay in HepG2 cells. Choline uptake was determined in cells treated for $10 \mathrm{~min}, 24 \mathrm{~h}$, and $48 \mathrm{~h}$ soluble Ff35 or Ff35-BMNPs. Results are normalized to their respective control. These experiments were performed three times in triplicates. ${ }^{*} p<0.05,{ }^{* *} p<0.001$ compared to their respective controls.

However, despite the fact that Ff35-BMNPs had little effect on the uptake of choline, it produced a marked decrease in cell proliferation, as mentioned above, similar to that observed in cells treated with soluble Ff35 at the same concentration (Figure 4B). This is very important because, by coupling Ff35 to the BMNPs, the antiproliferative effect of the compound is maintained as if Ff35 was soluble, whereas any secondary effects associated to the inhibition of choline uptake induced by soluble Ff35 
are avoided or reduced. This new property improves the potential clinical use of Ff35 that would be otherwise impeded.

TEM was used to visualize the internalization of BMNPs or Ff35-BMNPs (concentration of Ff35 was $1 \mu \mathrm{M}$ and BMNPs was $300 \mu \mathrm{g} \mathrm{mL} \mathrm{m}^{-1}$ ), and to determine the possible morphological changes caused by Ff35-BMNPs exposure. Ultrastructural analysis by TEM showed that BMNPs were internalized in the cells by endocytosis (Figure 6). Control cells (Figure 6A,B) showed mitochondria having a dense matrix as well as many cisternae of rough endoplasmic reticulum (ER) well structured, indicating absence of cell damage. No ultrastructural cell damage was observed following BMNPs internalization until $24 \mathrm{~h}$ incubation (Figure 6C,D), confirming the cell biocompatibility of these nanoparticles at a concentration of $300 \mu \mathrm{g} \mathrm{mL}^{-1}$. Both the BMNPs (Figure 6C,D) and Ff35-BMNPs (Figure 6E,F) were internalized via endocytosis and sorted into endosomes. As it can be seen, cells treated with Ff35-BMNPs showed ultrastructural alteration, such as a notable dilatation of perinuclear space increasing separation of two nuclear membranes, loss of mitochondrial density, and an abnormal shape. In general, the cells exposed to the BMNPs showed a similar appearance to control cells, with not significant structural alterations. These experiments confirm the cell damage following upon Ff35-BMNPs observed above, and explain why, while soluble Ff35 inhibits choline uptake, Ff35-BMNPs do not. While soluble Ff35 requires choline transporter to enter the cell, Ff35-BMNPs enter the cells by endocytosis, and thus, via a method that does not depend on choline transporters. Again, these results open the possibility for a clinical use of ChoK $\alpha 1$ inhibitors by making their uptake by the cells independent of choline transporters. Moreover, the experiments of the present study provide a protocol that allows us to disentangle whether the cytotoxic activity of a ChoK $\alpha 1$ inhibitor such a Ff35 is due to the selective inhibition of the enzyme, or on the contrary, due to the nonselective inhibition of the choline uptake by the cell as an undesirable secondary effect. This protocol could be standardized and extended to other molecules.

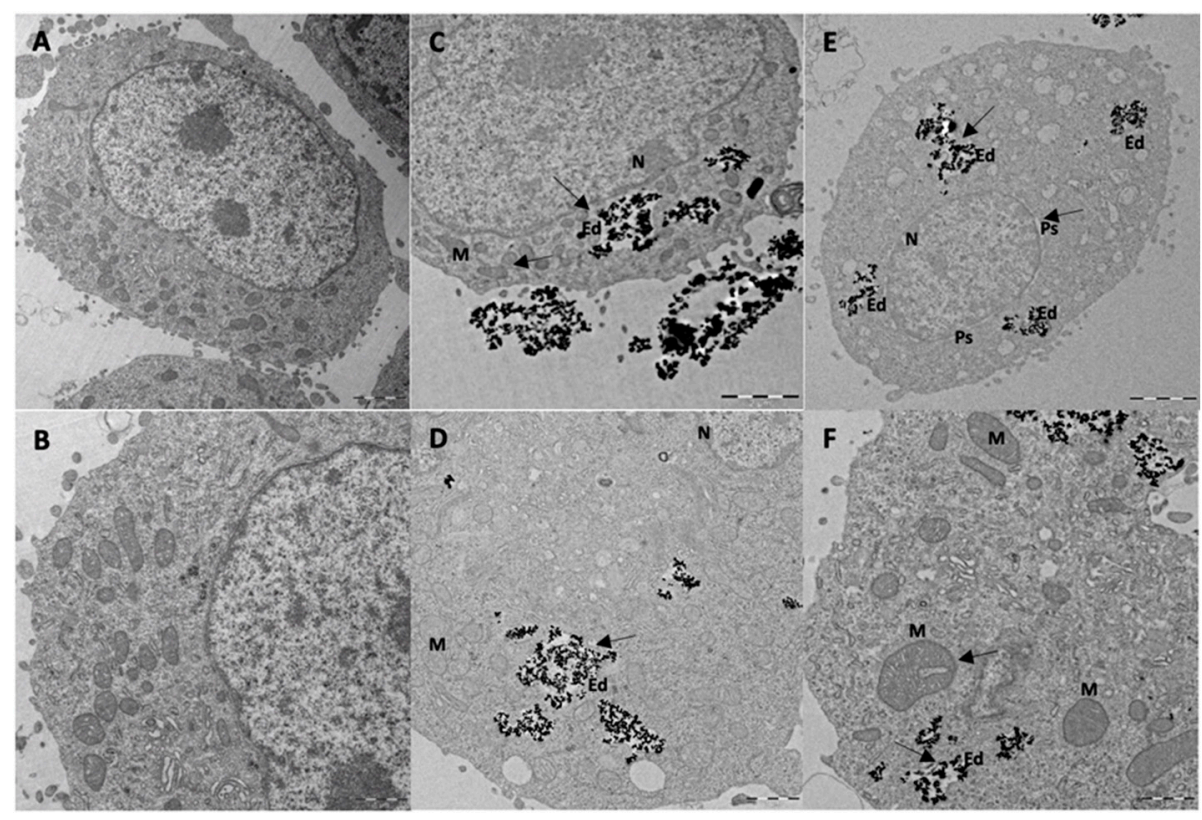

Figure 6. Internalization of BMNPs and Ff35-BMNPs. Ultrastructural alterations produced by Ff35-BMNPs. (A,B): Control HepG2 cells. (C,D): HepG2 cell exposed to BMNPs has ultrastructure similar to control cells. (E,F): Treatment with Ff35-BMNPs (concentration of BMNPs was $300 \mu \mathrm{g} \mathrm{mL}$ and Ff35 was $1 \mu \mathrm{M}$ ). Perinuclear space (Ps) is visible. The two nuclear membranes were separated showing a dilatation of the Ps. It is notably mitochondrial (M) rarefaction, disorganization, and dilatation. Both BMNPs and Ff35-BMNPs were internalized by HepG2 cells via endocytosis and compartmentalized in endosomes (Ed). Scale bar corresponds to $2 \mu \mathrm{m}(\mathrm{A}, \mathrm{C}, \mathrm{E})$ and $1 \mu \mathrm{m}(\mathrm{B}, \mathrm{D}, \mathrm{F})$. 
We consider now the effect of hyperthermia and the combination hyperthermia-Ff35 on cell proliferation. In all cases, the HepG2 cells were subjected to the magnetic field for periods of 1, 2, and $3 \mathrm{~h}$. We assume that, according to generally accepted results, tumor cells are more sensitive than healthy ones to a temperature increase [26], and, although $43^{\circ} \mathrm{C}$ is widely accepted as a common threshold for apoptosis of various cancer cells, many reports indicate that different thermal sensitivities exist among different cell lines [27]. Hence, preliminary experiments aimed at setting the optimal conditions of hyperthermia in HepG2 with the used BMNPs either bare or functionalized with Ff35. Figure 7 shows the effect of hyperthermia on the viability the cells, in comparison with cells not subjected to the magnetic field. Hyperthermia reinforced cytotoxicity on both cells treated with BMNPs and, much more so, on cells treated with Ff35-BMNPs. As it can be observed, after $2 \mathrm{~h}$ (and also $3 \mathrm{~h}$ ) of hyperthermia regime there was a significant decrease in viability ( $73 \%$ after $2 \mathrm{~h}$ and $79 \%$ after $3 \mathrm{~h}$ ) of cells maintained in the presence of BMNPs and AC field, revealing the cytotoxic effect of hyperthermia. However, there were not significant differences between these two different times. On other hand, significant differences in viability were found when the cells were treated with Ff35-BMNPs, with and without field. It is shown in Figure 7 that the viability of cells treated with Ff35-BMNPs without hyperthermia reached $67 \%$, these values being lower in those cells treated with Ff35-BMNPs with hyperthermia ( $54.8 \%$ for $1 \mathrm{~h}, 49.7 \%$ for $2 \mathrm{~h}$, and $44.5 \%$ for $3 \mathrm{~h}$ ). Since BMNPs are cytocompatible, these results show that the temperature rise induced by them upon application of an alternating magnetic field was responsible for the reduction in cell viability. However, such reduction was more evident and faster upon the combination of drug release and hyperthermia. It is proposed that hyperthermia may not only increase the local temperature, but also trigger the release of Ff35 from the BMNPs in the cells, as already demonstrated to occur for other compounds [28].

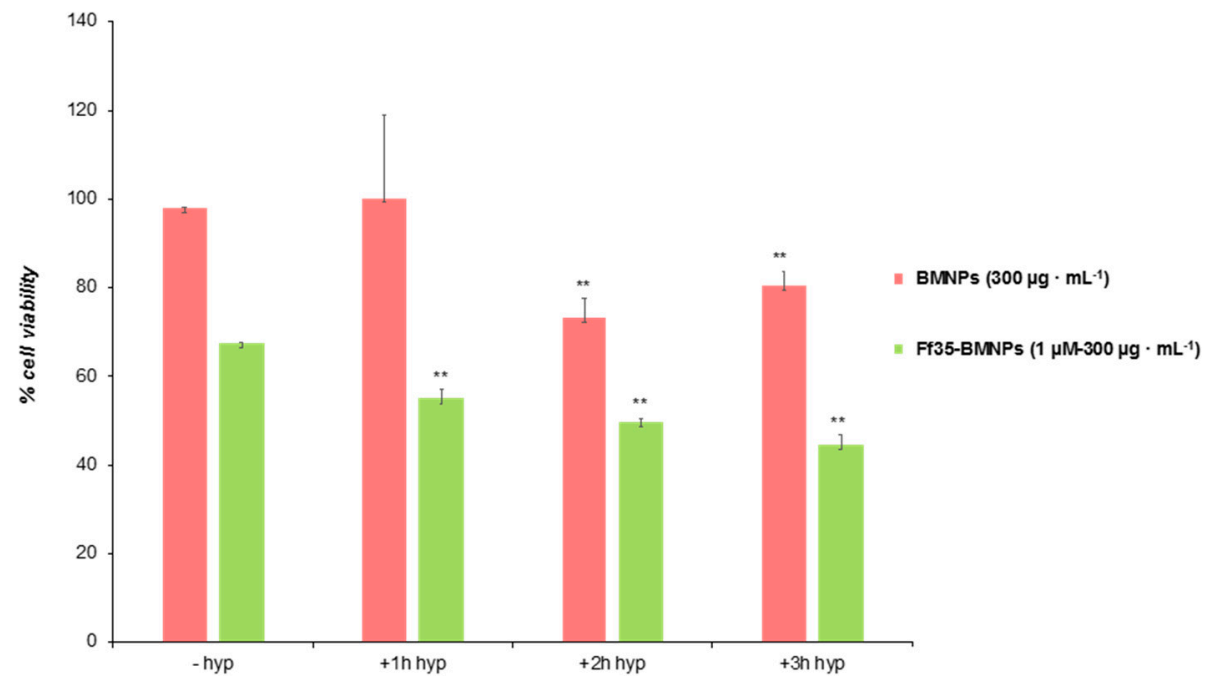

Figure 7. Effects of Ff35-BMNPs and hyperthermia on cell proliferation in HepG2 cells. HepG2 cells growing in log-phase were incubated with MEM/10\% FBS in the absence or presence Ff35-BMNPs (concentration of Ff35 was $1 \mu \mathrm{M}$ and BMNPs was $300 \mu \mathrm{g} \mathrm{mL}{ }^{-1}$ ) for $24 \mathrm{~h}$, and exposed to an alternative magnetic field for 1, 2, or $3 \mathrm{~h}$. Cell number was determined by the MTT assay and expressed as percentage of control cells. Percentage of viability is normalized to that for the control cells. Results represent the mean \pm SEM of three independent experiments conducted in triplicate. ${ }^{* *} p<0.001$, when compared with their respective control values.

Therefore, these results open the door, not only to the potential use of ChoK $\alpha 1$ inhibitors without the secondary effect linked to the inhibition of choline uptake, but also, to the application of a dual therapy based on targeted drug release and hyperthermia to potentiate the cytotoxic activity of these compounds on tumor cells. 


\section{Conclusions}

In summary, this study shows that the coupling of the ChoK $\alpha 1$ inhibitor Ff35 to BMNPs offers great advantages. On one hand, since the nanocarrier is a magnetic nanoparticle, it opens the possibility of a magnetic guidance to the target site through the application of a continuous magnetic field. Also, it offers the possibility of also using the nanocarrier as a hyperthermia agent, thus combining the cytotoxic effect of the molecule with the cytotoxic effect induced by hyperthermia and the triggering of drug release from the BMNPs that hyperthermia induces. Finally, and no less important, it offers the potential of Ff35 entering the cell independently of the choline transporters. This is crucial, as the coupling of Ff35-BMNPs allows the compound to exert a cytotoxic activity comparable to that of the soluble compound while avoiding the secondary effect linked to the inhibition of choline uptake. Also, it provides a protocol that could be extensible to other molecules to disentangle the cytotoxic effect of the drug in terms on enzyme inhibition and/or inhibition of choline uptake. Therefore, the novel design of the nanoassemblies of Ff35-BMNPs showed in this study and the demonstration of the activity of such a compound without interfering in the choline uptake are crucial results, as they would allow the potential use of these ChoK $\alpha 1$ inhibitors as antitumoral drugs that would otherwise be compromised.

Author Contributions: Y.J. and A.S.-L. contributed equally to this work. Conceptualization, G.R.I., M.P.C.-J., and C.J.-L.; methodology, Y.J., A.S.-L., A.P., F.V., G.R.I., J.V.-G., I.P.-P., F.J.A.-T., L.C.L.-C., M.P.C.-J., and C.J.-L.; validation, Y.J., A.S.-L., A.P., F.V., G.R.I., J.V.-G., I.P.-P., F.J.A.-T., L.C.L.-C., M.P.C.-J., and C.J.-L.; formal analysis, Y.J., A.S.-L., G.R.I., M.P.C.-J., and C.J.-L.; investigation, Y.J., A.S.-L., A.P., F.V., G.R.I., J.V.-G., I.P.-P., and F.J.A.-T.; resources, M.P.C.-J. and C.J.-L.; writing-original draft preparation, Y.J., A.S.-L., G.R.I., M.P.C.-J., and C.J.-L.; writing-review and editing, Y.J., A.S.-L., A.P., F.V., G.R.I., M.P.C.-J., and C.J.-L.; supervision, M.P.C.-J. and C.J.-L.; project administration, M.P.C.-J. and C.J.-L.; funding acquisition, G.R.I., M.P.C.-J., and C.J.-L.

Funding: This research was funded by the Ministerio de Economía y Competitividad (CGL2013-46612 and CGL2016-76723 projects), Ramón y Cajal programme (RYC-2014-16901) and the Fondo Europeo de Desarrollo Regional (FEDER). Also, this research was aided by the Andalusian regional government (CTS-236).

Acknowledgments: Ylenia Jabalera wants to acknowledge a FPU2016 grant (ref. FPU16_04580) from the Ministerio de Educación, Ciencia y Deporte y Competitividad (Spain) and Unidad Cientifica de Excelencia UCE-PP2016-05 of the University of Granada. Alberto Sola-Leyva holds a Formación de Doctores 2018 grant (ref. PRE2018-085440) from the Ministerio de Ciencia, Innovación y Universidades (Spain). Inmaculada Pérez-Prieto holds the fellowship called "Becas de Iniciación a la Investigación" from the Plan Propio de Investigación de la Universidad de Granada. Finally, thanks go to the CIC personnel of the University of Granada for technical assistance in the TEM.

Conflicts of Interest: The authors declare no conflict of interest.

\section{References}

1. Siegel, R.L.; Miller, K.D.; Jemal, A. Cancer statistics, 2018. CA Cancer J. Clin. 2018, 68, 7-30. [CrossRef] [PubMed]

2. Hanahan, D.; Weinberg, R.A. The Hallmarks of Cancer. Cell 2000, 100, 57-70. [CrossRef]

3. Huang, C.; Freter, C. Lipid metabolism, apoptosis and cancer therapy. Int. J. Mol. Sci. 2015, 16, 924-949. [CrossRef] [PubMed]

4. Galbraith, L.; Leung, H.Y.; Ahmad, I. Lipid pathway deregulation in advanced prostate cancer. Pharmacol. Res. 2018, 131, 177-184. [CrossRef] [PubMed]

5. Glunde, K.; Bhujwalla, Z.M.; Ronen, S.M. Choline metabolism in malignant transformation. Nat. Rev. Cancer 2011, 11, 835-848. [CrossRef] [PubMed]

6. Cao, M.D.; Cheng, M.; Rizwan, A.; Jiang, L.; Krishnamachary, B.; Bhujwalla, Z.M.; Bathen, T.F.; Glunde, K. Targeting choline phospholipid metabolism: GDPD5 and GDPD6 silencing decrease breast cancer cell proliferation, migration, and invasion. NMR Biomed. 2016, 29, 1098-1107. [CrossRef] [PubMed]

7. Iorio, E.; Caramujo, M.J.; Cecchetti, S.; Spadaro, F.; Carpinelli, G.; Canese, R.; Podo, F. Key Players in Choline Metabolic Reprograming in Triple-Negative Breast Cancer. Front. Oncol. 2016, 6, 205. [CrossRef]

8. Van der Veen, J.N.; Kennelly, J.P.; Wan, S.; Vance, J.E.; Vance, D.E.; Jacobs, R.L. The critical role of phosphatidylcholine and phosphatidylethanolamine metabolism in health and disease. Biochim. Biophys. Acta Biomembr. 2017, 1859, 1558-1572. [CrossRef] 
9. Yalcin, A.; Clem, B.; Makoni, S.; Clem, A.; Nelson, K.; Thornburg, J.; Siow, D.; Lane, A.N.; Brock, S.E.; Goswami, U.; et al. Selective inhibition of choline kinase simultaneously attenuates MAPK and PI3K/AKT signaling. Oncogene 2010, 29, 139-149. [CrossRef]

10. Mori, N.; Glunde, K.; Takagi, T.; Raman, V.; Bhujwalla, Z.M. Choline Kinase Down-regulation Increases the Effect of 5-Fluorouracil in Breast Cancer Cells. Cancer Res. 2007, 67, 11284-11290. [CrossRef]

11. Chen, Z.; Krishnamachary, B.; Bhujwalla, Z. Degradable Dextran Nanopolymer as a Carrier for Choline Kinase (ChoK) siRNA Cancer Therapy. Nanomaterials 2016, 6, 34. [CrossRef]

12. Schiaffino-Ortega, S.; Baglioni, E.; Mariotto, E.; Bortolozzi, R.; Serrán-Aguilera, L.; Ríos-Marco, P.; Carrasco-Jimenez, M.P.; Gallo, M.A.; Hurtado-Guerrero, R.; Marco, C.; et al. Design, synthesis, crystallization and biological evaluation of new symmetrical biscationic compounds as selective inhibitors of human Choline Kinase $\alpha 1$ (ChoK $\alpha 1)$. Sci. Rep. 2016, 6, 23793. [CrossRef]

13. Arlauckas, S.P.; Popov, A.V.; Delikatny, E.J. Choline kinase alpha-Putting the ChoK-hold on tumor metabolism. Prog. Lipid Res. 2016, 63, 28-40. [CrossRef]

14. Lacal, J.C. Choline kinase as a precision medicine target for therapy in cancer, autoimmune diseases and malaria. Precis. Med. 2015, 2, 980.

15. Bioisoterism, N.V. Review-An Biological Modification. World J. Pharm. Pharm. Sci. 2017, 6, 1918-1949.

16. Sola-Leyva, A.; Lopez-Cara, L.C.; Ríos-Marco, P.; Ríos, A.; Marco, C.; Carrasco-Jiménez, M.P. Choline kinase inhibitors EB-3D and EB-3P interferes with lipid homeostasis in HepG2 cells. Sci. Rep. 2019, 9, 5109. [CrossRef]

17. Prozorov, T.; Bazylinski, D.A.; Mallapragada, S.K.; Prozorov, R. Novel magnetic nanomaterials inspired by magnetotactic bacteria: Topical review. Mater. Sci. Eng. R Rep. 2013, 74, 133-172. [CrossRef]

18. García Rubia, G.; Peigneux, A.; Jabalera, Y.; Puerma, J.; Oltolina, F.; Elert, K.; Colangelo, D.; Gómez Morales, J.; Prat, M.; Jimenez-Lopez, C. pH-Dependent Adsorption Release of Doxorubicin on MamC-Biomimetic Magnetite Nanoparticles. Langmuir 2018, 34, 13713-13724. [CrossRef]

19. Valverde-Tercedor, C.; Montalbán-López, M.; Perez-Gonzalez, T.; Sanchez-Quesada, M.S.; Prozorov, T.; Pineda-Molina, E.; Fernandez-Vivas, M.A.; Rodriguez-Navarro, A.B.; Trubitsyn, D.; Bazylinski, D.A.; et al. Size control of In Vitro synthesized magnetite crystals by the MamC protein of Magnetococcus marinus strain MC-1. Appl. Microbiol. Biotechnol. 2015, 99, 5109-5121. [CrossRef]

20. Perez-Gonzalez, T.; Rodriguez-Navarro, A.; Jimenez-Lopez, C. Inorganic Magnetite Precipitation at $25^{\circ} \mathrm{C}$ : A Low-Cost Inorganic Coprecipitation Method. J. Supercond. Nov. Magn. 2010, 24, 549-557. [CrossRef]

21. Turiel, E.; Perez-Conde, C.; Martin-Esteban, A. Assessment of the cross-reactivity and binding sites characterisation of a propazine-imprinted polymer using the Langmuir-Freundlich isotherm. Analyst 2003, 128, 137-141. [CrossRef]

22. Jiménez-López, J.M.; Carrasco, M.P.; Segovia, J.L.; Marco, C. Hexadecylphosphocholine inhibits phosphatidylcholine biosynthesis and the proliferation of HepG2 cells. Eur. J. Biochem. 2002, 269, 4649-4655. [CrossRef]

23. Reynolds, E.S. The use of lead citrate at high $\mathrm{pH}$ as an electron-opaque stain in electron microscopy. J. Cell Biol. 1963, 17, 208-212. [CrossRef]

24. Iafisco, M.; Drouet, C.; Adamiano, A.; Pascaud, P.; Montesi, M.; Panseri, S.; Sarda, S.; Tampieri, A. Superparamagnetic iron-doped nanocrystalline apatite as a delivery system for doxorubicin. J. Mater. Chem. B 2016, 4, 57-70. [CrossRef]

25. Geisow, M.J.; Evans, W.H. pH in the endosome. Measurements during pinocytosis and receptor-mediated endocytosis. Exp. Cell Res. 1984, 150, 36-46. [CrossRef]

26. Chicheł, A.; Skowronek, J.; Kubaszewska, M.; Kanikowski, M. Hyperthermia-description of a method and a review of clinical applications. Rep. Pract. Oncol. Radiother. 2007, 12, 267-275. [CrossRef]

27. Lim, C.-U.; Zhang, Y.; Fox, M.H. Cell cycle dependent apoptosis and cell cycle blocks induced by hyperthermia in HL-60 cells. Int. J. Hyperth. 2006, 22, 77-91. [CrossRef]

28. Iglesias, G.R.; Reyes-Ortega, F.; Fernandez, B.L.C.; Delgado, Á.V. Hyperthermia-triggered gemcitabine release from polymer-coated magnetite nanoparticles. Polymers 2018, 10, 269. [CrossRef]

(C) 2019 by the authors. Licensee MDPI, Basel, Switzerland. This article is an open access article distributed under the terms and conditions of the Creative Commons Attribution (CC BY) license (http://creativecommons.org/licenses/by/4.0/). 